\title{
Methionine restriction affects the phenotypic and transcriptional response of rainbow trout (Oncorhynchus mykiss) to carbohydrate-enriched diets
}

\author{
Paul M. Craig* and Thomas W. Moon \\ Department of Biology, Centre for Advanced Research in Environmental Genomics, University of Ottawa, \\ 30 Marie Curie, Ottawa, Canada, ON K1N 6N5
}

(Submitted 12 January 2012 - Final revision received 13 March 2012 - Accepted 27 March 2012 - First published online 15 May 2012)

\section{Abstract}

Mammalian studies report that methionine restriction (MR) as a dietary regimen extends life span, delays the onset of age-related diseases and enhances fat oxidation in obese subjects with metabolic syndromes. However, the underlying cellular signalling pathways are poorly understood. Rainbow trout (Oncorhynchus mykiss) is a glucose-intolerant species, providing an excellent model for the study of carbohydrate metabolism. MR diets in combination with $12 \%(+/-)$ and $22 \%(+/-)$ carbohydrate-rich meals were fed to rainbow trout for a period of 8 weeks and phenotypic and transcript expression changes in the liver and white muscle were assessed. Fish fed MR diets, irrespective of carbohydrate load, were shown to abolish the glucose-intolerant phenotype $6 \mathrm{~h}$ post-feeding. There was a distinct switch in glucose and glycogen content in the liver of fish fed MR diets, with a significantly higher concentration of glycogen, suggesting reduced glycolytic capacity. Transcriptional responses to MR demonstrated decreased expression of hepatic fatty acid synthase, sterol regulatory binding protein 1, PPAR $\gamma$ coactivator 1- $\alpha$ and PPAR $\alpha$, indicative of a reduction in the de novo synthesis of fatty acids and cholesterol, and a potential decrease in hepatic fat oxidative capacity. Muscle adenylate charge was depressed under MR, and increased expression of AMP-activated protein kinase $\alpha 1$ was detected, indicative of reduced energy availability. Total DNA methylation showed that carbohydrate load, rather than MR, dictated hypomethylation of genomic DNA. This is the first study which demonstrates that MR can abolish a glucoseintolerant phenotype in trout, and identifies trout as a suitable model for studying metabolic syndromes.

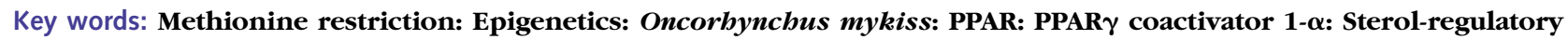
element binding protein: AMP-activated protein kinase $\alpha 1$

Rainbow trout (Oncorbynchus mykiss) is an economically important fish species. Farmed trout are a valuable asset to the aquaculture industry, and there is significant pressure to reduce the use of protein-rich fishmeal-based diets currently fed to trout and other cultured species, and move towards a more sustainable plant-based meal as a means to reduce production costs and alleviate the burden on wild fish stocks ${ }^{(1,2)}$. Furthermore, high-carbohydrate diets are desirable as they can increase growth rate and turnover rates in aquaculture practices, although how these enriched carbohydrate loads are metabolised and stored in trout remains controversial ${ }^{(3,4)}$. Trout are carnivorous in nature with a limited ability to use digestible carbohydrates and are often classified as 'glucose intolerant ${ }^{\text {(3) }}$. This is a well-established phenomenon characterised by prolonged hyperglycaemia and elevated plasma insulin levels after a carbohydrate-rich meal, and is similar in nature to the human metabolic disorder, type 2 diabetes ${ }^{(5)}$. Of particular interest to the present study is how a carnivorous fish, such as rainbow trout, can metabolise large quantities of carbohydrates and whether trout can be used as a model vertebrate species for the study of human metabolic disorders.

Recent mammalian studies reported that the dietary restriction of a single amino acid, methionine (Met), decreased mitochondria reactive oxygen species generation and oxidative damage in mice ${ }^{(6,7)}$, increased maximum longevity in rodents $^{(8)}$ and increased fat oxidation in human subjects with the metabolic syndrome ${ }^{(9)}$. In spite of the many studies examining the effects of Met restriction (MR), the direct mechanism involved in altering energy expenditure and metabolism by MR remains unknown. However, as a key methyl donor,

Abbreviations: $12 \%+, 12 \%$ carbohydrate load with $1.5 \%$ methionine content; $12 \%-$, $12 \%$ carbohydrate load with $0 \%$ methionine; $22 \%+, 22 \%$ carbohydrate load with 1.5\% methionine content; $22 \%$ - , 22\% carbohydrate load with 0\% methionine; 5-mC, 5-methylcytosine; Adipo, adiponectin; AEC, adenylate energy charge; AMPK, AMP-activated protein kinase; AMPK $\alpha 1$, AMP-activated protein kinase $\alpha$ subunit 1; cDNA, complementary DNA; CPT1, carnitine palmitoyl transferase 1; FAS, fatty acid synthase; GK, glucokinase; HK, hexokinase; Met, methionine; MR, methionine restriction; PGC-1 $\alpha$, PPAR $\gamma$ coactivator $1-\alpha$; SREBP1, sterol-regulatory element binding protein 1. 
Met may play a role in the epigenetic regulation of gene transcription. MR in rodents does reduce the hepatic content of $S$-adenosylmethionine, making an impact on the endogenous methyl donor pool, which has been demonstrated to decrease the degree of total DNA methylation ${ }^{(10,11)}$. Activation of normally silenced genes may be the driving force in relation to MR and altered energy expenditure and carbohydrate metabolism. To our knowledge, no study has examined the epigenetic effects of dietary Met manipulation in rainbow trout.

Supplementation of Met, and other essential amino acids such as L-leucine and L-lysine, is required for plant-based fish diets to match the nutritional and amino acid requirements of fish ${ }^{(12-14)}$. Met supplementation is reported to improve the growth of rainbow trout ${ }^{(15)}$ and MR resulted in increased hepatic fatty acid synthase (FAS) activity, suggesting Met involvement in lipid metabolism ${ }^{(16)}$. Furthermore, Lansard et $a l^{(17,18)}$ reported that manipulation of the aforementioned essential amino acids in trout hepatocytes regulated the expression of genes involved in carbohydrate and lipid metabolism. In fish, consumed carbohydrates in excess are converted to fats and stored in the liver, and recent evidence suggests that this de novo hepatic lipogenesis is dependent upon an insulin-stimulated pathway ${ }^{(19)}$. MR is reported to shift fuel utilisation from glucose to fat oxidation in rats ${ }^{(20)}$, and, by extension, we predict that MR in trout fed variable carbohydrate diets will have a similar impact on the transcripts involved in lipid and carbohydrate metabolism, as well as shifts in fuel usage, storage and energy availability.

The present study takes the initial steps in identifying the phenotypic impacts of MR in vivo, and provides further evidence of how carnivorous fish regulate ingested carbohydrates. Here, we fed trout semi-purified diets, in which known amounts of all amino acids, lipids and digestible carbohydrates were quantified. These diets consisted of a nominal (12\%) and high (22\%) carbohydrate load both with Met and MR. Transcripts involved in energy regulation (AMP-activated protein kinase (AMPK); carnitine palmitoyl transferase 1 (CPT1); PPAR $\gamma$ coactivator 1- $\alpha$ (PGC-1 $\alpha)$; PPAR $\alpha$ ), glycolysis (glucokinase (GK); hexokinase (HK)), lipogenesis (FAS; sterolregulatory element binding protein 1 (SREBP1)), and a newly identified regulator of glucose metabolism and fatty acid catabolism (adiponectin, Adipo) were assessed in both liver and muscle tissue. Parameters of growth, tissue metabolite concentrations of carbohydrates and lipids, liver GK and muscle HK activity, and adenylate energy charge (AEC) were determined for impacts on available fuels and energy pools. Finally, the epigenetic influence of MR was determined from total genomic DNA methylation status of muscle and liver tissues.

\section{Materials and methods \\ Fish}

Female rainbow trout (O. mykiss; $n$ 32; eight per treatment) were purchased locally (Linwood Acres Trout Farm). Fish were initially sorted for weight (approximately $75 \mathrm{~g}$ ) and acclimated to $13^{\circ} \mathrm{C}$ in $1.2 \mathrm{~m}^{3}$ tanks for 2 weeks before the start of the experiment. During this time, fish were fed ad libitum commercial trout feed (3 PT classic floating grower feed; Martin Mills). Tanks were supplied continuously with water from the City of Ottawa that was oxygenated and dechloraminated at the University of Ottawa Aquatic Care Facility. All fish were held under a photoperiod regime that mimicked the City of Ottawa natural light cycle. All experiments were conducted under a protocol approved by the University of Ottawa Animal Care Protocol Review Committee and undertaken in accordance with institutional animal care guidelines adhering to those of the Canadian Council on Animal Care.

\section{Feeding experiment}

Semi-purified diets were purchased from Dyets, Inc. Overall, four diets were purchased, which consisted of either $12 \%$ or $22 \%$ carbohydrate load with $(1.5 \%$ of total) or without $(0 \%$ of total) Met (+/-, respectively). The $12 \%+$ group was considered the control group. The composition was modified across all experimental feeds to ensure that all diets were isoenergetic and isonitrogenous, by manipulating the essential

Table 1. Amino acid, lipid and carbohydrate content $(\mathrm{g} / 100 \mathrm{~g})$ of diets used in the study*

\begin{tabular}{|c|c|c|c|c|}
\hline Ingredient & $12 \%+$ & $12 \%-$ & $22 \%+$ & $22 \%-$ \\
\hline L-Ala† & 3.5 & 4.4 & 3.3 & 4.1 \\
\hline L-Arg & 4.7 & 4.7 & 4.4 & 4.4 \\
\hline L-Asp & 4.9 & 5.0 & 4.7 & 4.7 \\
\hline L-Cystine & 0.5 & 0.5 & 0.5 & 0.5 \\
\hline L-Glu & $7 \cdot 7$ & $7 \cdot 8$ & $7 \cdot 3$ & $7 \cdot 3$ \\
\hline Gly & 4.0 & $4 \cdot 1$ & 3.8 & 3.8 \\
\hline L-Histine & 1.6 & 1.6 & 1.5 & 1.5 \\
\hline L-Ile & $2 \cdot 2$ & $2 \cdot 2$ & $2 \cdot 1$ & $2 \cdot 1$ \\
\hline L-Leu & 3.8 & 3.8 & 3.6 & 3.6 \\
\hline L-Lys-HCl & $5 \cdot 0$ & 5.0 & 4.7 & 4.7 \\
\hline L-Met & 1.5 & 0.0 & 1.4 & 0.0 \\
\hline L-Phe & $2 \cdot 4$ & $2 \cdot 4$ & $2 \cdot 3$ & $2 \cdot 3$ \\
\hline L-Pro & $2 \cdot 8$ & $2 \cdot 8$ & $2 \cdot 6$ & $2 \cdot 6$ \\
\hline L-Ser & 2.5 & 2.5 & $2 \cdot 3$ & $2 \cdot 3$ \\
\hline L-Thr & $2 \cdot 3$ & $2 \cdot 3$ & $2 \cdot 2$ & $2 \cdot 2$ \\
\hline L-Trp & 0.4 & 0.4 & 0.4 & 0.4 \\
\hline L-Tyr & $2 \cdot 2$ & $2 \cdot 2$ & $2 \cdot 0$ & $2 \cdot 0$ \\
\hline L-Val & $2 \cdot 4$ & $2 \cdot 4$ & $2 \cdot 3$ & $2 \cdot 3$ \\
\hline Soyabean oilt & $5 \cdot 3$ & 5.5 & 3.0 & 3.1 \\
\hline Menhaden oilt & $5 \cdot 3$ & 5.5 & 3.0 & $3 \cdot 1$ \\
\hline Dextrin & 6.6 & 6.7 & $11 \cdot 1$ & 11.2 \\
\hline Dyetrose & $5 \cdot 7$ & $5 \cdot 7$ & $10 \cdot 2$ & 10.2 \\
\hline Cellulose & 8.8 & $8 \cdot 8$ & 8.3 & $8 \cdot 3$ \\
\hline Gelatin & 8.5 & 8.5 & 8.0 & 8.0 \\
\hline Salt mix & $4 \cdot 2$ & 4.3 & 4.0 & 4.0 \\
\hline Vitamin mix & 1.1 & 1.1 & 1.0 & 1.0 \\
\hline Total & $100 \cdot 0$ & $100 \cdot 0$ & $100 \cdot 0$ & $100 \cdot 0$ \\
\hline \multicolumn{5}{|l|}{ Analytical composition } \\
\hline DM (\%) & 96.6 & 96.6 & $95 \cdot 3$ & 95 \\
\hline Protein (\% DM) & $60 \cdot 8$ & 60.5 & $56 \cdot 6$ & $56 \cdot 1$ \\
\hline Lipid (\% DM) & $10 \cdot 3$ & $10 \cdot 6$ & 5.7 & 6.0 \\
\hline Carbohydrate (\% DM) & 11.9 & 11.9 & $20 \cdot 3$ & $20 \cdot 3$ \\
\hline Gross energy (kJ/q DM) & 14.9 & 14.9 & 14.7 & 14.7 \\
\hline
\end{tabular}

$12 \%+, 12 \%$ Carbohydrate load with $1.5 \%$ methionine content; $12 \%-, 12 \%$ carbohydrate load with $0 \%$ methionine; $22 \%+, 22 \%$ carbohydrate load with $1.5 \%$ methionine content; $22 \%-, 22 \%$ carbohydrate load with $0 \%$ methionine. * Dietary analysis was provided by Dyets, Inc.

† Lipids and L-alanine levels were adjusted to ensure that all diets were both isoenergetic and isonitrogenous. 
oils and L-alanine concentrations (Table 1). Dietary composition analysis was conducted by the supplier and provided to us as total available energy (Table 1). The food was additionally coated with $1 \%(\mathrm{w} / \mathrm{v})$ cod liver oil (Carlson ${ }^{\circledR}$ Nutritional Supplements) to ensure palatability. Food intake was assessed with visual inspection of ingestion and daily accumulation of faeces at the bottom of the tank. Fish were fed diets amounting to $1 \%$ body weight daily over a period of 8 weeks, after which the fish were terminally anaesthetised $6 \mathrm{~h}$ post-feeding on the final day, corresponding to the peak in blood glucose in trout ${ }^{(21)}$. Fish were weighed and sampled for blood, liver and white muscle tissue. A small blood sample was taken for haematocrit, and the remaining sample was immediately centrifuged, plasma separated and frozen at $-20^{\circ} \mathrm{C}$. All tissues were freeze-clamped in liquid $\mathrm{N}_{2}$ and stored at $-80^{\circ} \mathrm{C}$ until processed.

\section{Fish oxygen consumption}

Before the termination of the feeding experiment, whole-tank oxygen consumption was determined $6 \mathrm{~h}$ post-feeding to assess differences in oxygen consumption between treatments. Briefly, tanks were covered with a plastic bag to ensure that there was a sufficient boundary between the surrounding air and tank water, and then a sympHony dissolved oxygen probe (VWR) was submerged into the tank and allowed to temperature-equilibrate. Following this, water and airflows were suspended to the tank and dissolved oxygen was recorded for a period of $1 \mathrm{~h}$. This protocol was repeated for each tank ( $n$ 6) for the week leading up to the termination of the experiment. The tank-wise metabolic rate $\left(\mathrm{MO}_{2} ; \mathrm{mg} \mathrm{O}_{2} / \mathrm{kg}\right.$ per h$)$ was determined based on the total weight of fish within the tank.

\section{Blood and tissue metabolites}

All chemicals were purchased from Sigma-Aldrich, and the reaction buffers were prepared fresh daily. Liver and muscle tissues ( $n$ 8) were powdered under liquid $\mathrm{N}_{2}$ using a motor and pestle from which glucose and glycogen were extracted using approximately $50 \mathrm{mg}$ of powdered tissue to $0.5 \mathrm{ml}$ of ice-cold $\mathrm{HClO}_{4}(6 \%)$ and homogenised for $20 \mathrm{~s}$ using a polytron-style homogeniser (Polytron PT2100; Kinematica). Aliquots used for glycogen analysis were neutralised with $\mathrm{NaHCO}_{3}$, enzymatically digested according to Hassid \& Abraham $^{(22)}$, and all samples were assayed for glucose spectrophotometrically following the protocol of Bergmeyer ${ }^{(23)}$. Plasma glucose was analysed directly as mentioned previously. For the measurements of adenylates, a modified Vialight ATP assay was employed (Lonza). Briefly, 10-15 mg of powdered liver and muscle tissues were added to thirty volumes of lysis reagent (provided in the kit), and the tissues were allowed to lyse at room temperature for $10 \mathrm{~min}$. For the determination of AMP, ADP and ATP, $100 \mu \mathrm{l}$ of lysate were either enzymatically digested in $300 \mu \mathrm{l}$ AMP tricine buffer $(40 \mathrm{U} / \mathrm{ml}$ pyruvate kinase, $100 \mathrm{U} / \mathrm{ml}$ myokinase, $40 \mu \mathrm{m}$-phosphoenolpyruvate, $10 \mathrm{~mm}-\mathrm{KCl}, 40 \mathrm{~mm}$-tricine, $\mathrm{pH} 7.75$ ), $300 \mu \mathrm{l}$ ADP tricine buffer $(40 \mathrm{U} / \mathrm{ml}$ pyruvate kinase, $40 \mu \mathrm{m}$-phosphoenolpyruvate, $10 \mathrm{~mm}-\mathrm{KCl}, 40 \mathrm{~mm}$-tricine, $\mathrm{pH}$
7.75), or diluted in $300 \mu \mathrm{l}$ ATP tricine buffer $(10 \mathrm{~mm}-\mathrm{KCl}$, $40 \mathrm{~mm}$-tricine, $\mathrm{pH} 7 \cdot 75$ ) for $10 \mathrm{~min}$. Then, $150 \mu \mathrm{l}$ of digest were transferred to a ninety-six-well luminescence plate and $100 \mu \mathrm{l}$ of ATP monitoring reagent (provided in the kit) were added. The plate was incubated in the dark for 2 min and then read on an LMAXII 384 luminometer (Molecular Devices), and ATP concentrations were determined from a standard curve, spanning $10 \mathrm{~nm}$ to $10 \mu \mathrm{M}$, constructed from a purchased stock of standard specifically designed for bioluminescent determination of ATP (FLAAS-1VL, Sigma-Aldrich). AEC was calculated as: $\mathrm{AEC}=((\mathrm{ATP})+0 \cdot 5(\mathrm{ADP})) /((\mathrm{ATP})+(\mathrm{ADP})+(\mathrm{AMP}))$.

\section{Enzymatic activity}

GK (EC 2.7.1.2) and HK (EC 2.7.1.2) enzymatic activities were assessed for both liver and white muscle, respectively. Activities were determined as described by Panserat et al. by coupling ribulose-5-phosphate formation from glucose6-phosphate to the reduction of $\mathrm{NADP}^{+}$at $340 \mathrm{~nm}$. Activities were determined on a ninety-six-well microplate at $37^{\circ} \mathrm{C}$ and absorbance measured and recorded on a SpectraMAX PLus 384 microplate reader using SOFTmax software 4.6 (Molecular Devices). GK activity was corrected for glucose dehydrogenase activity (EC 1.1.1.47) as described ${ }^{(24)}$. Briefly, GK activity is determined as the total HK activity - low $K_{\mathrm{m}}$ HK activity $1 / 3$ glucose dehydrogenase activity. Enzyme activity (U/mg protein) is defined as $\mu \mathrm{mol}$ of substrate converted to produced, per min, expressed per mg of soluble protein.

\section{Lipid quantification}

Lipids were extracted from the liver and muscle tissues ( $n$ 8) using a 2:1 chloroform-methanol (Folch) extraction protocol. Briefly, $5 \mathrm{ml}$ of Folch were added to ground tissues, vortexed, and incubated for $20 \mathrm{~min}$ at room temperature; then, $2.5 \mathrm{ml}$ $2 \mathrm{M}-\mathrm{KCl}$ buffered with $5 \mathrm{~mm}$-EDTA were added, and the solution was vortexed and incubated for an additional $10 \mathrm{~min}$ before centrifugation at $2000 \mathrm{~g}$ for $3 \mathrm{~min}$. The lower phase was placed in a clean glass tube and the liquid was evaporated under $\mathrm{N}_{2}$ until only the lipid residue remained. The extracted lipids were reconstituted in $0.5 \mathrm{ml}$ ethylene glycol monomethyl diethyl ether. TAG and cholesterol were quantified from the tissue extracts using diagnostic kits, following the manufacturer's protocol (TECO Diagnostic). Plasma cholesterol and TAG were measured directly from the sample without extraction using the same kit. Phospholipids and total lipids were quantified using diagnostic kits from Wako Chemicals, following the manufacturer's protocol.

\section{Genomic DNA extraction and methylation assessment}

Liver and muscle tissues ( $n 5$ per tissue) were ground in liquid $\mathrm{N}_{2}$ and approximately $50 \mathrm{mg}$ of tissue were added to ten volumes of genomic DNA digestion buffer $(100 \mathrm{~mm}-\mathrm{NaCl}$, $10 \mathrm{~mm}$-Tris- $\mathrm{HCl}, 25 \mathrm{~mm}$-EDTA, $0.5 \%$ SDS, $0 \cdot 1 \mathrm{mg} / \mathrm{ml}$ proteinase $\mathrm{K}, \mathrm{pH} 8.0$ ), and incubated for $18 \mathrm{~h}$ at $50^{\circ} \mathrm{C}$. DNA was extracted from digested samples using standard phenol-chloroformisoamyl alcohol (25:24:1), and DNA was precipitated with 
7.5 $\mathrm{M}$-ammonium acetate and 100\% ethanol. The final DNA pellet was washed in $70 \%$ ethanol and re-suspended in TE buffer (10 mm-Tris-HCl, 1 mm-EDTA, pH 7·5). DNA was quantified using the Nanodrop ND-1000 (Fisher Scientific), diluted in TE buffer, and then re-quantified to ensure that 50-100 ng DNA were loaded into each well to assess DNA methylation status. The percentage of methylated DNA, as determined by the colorimetric quantification of 5-methylcytosine (5-mC), was measured using the MethylFlash ${ }^{\mathrm{TM}}$ Methylated DNA Quantification Kit (colorimetric; Epigentek), following the manufacturer's protocol.

\section{Quantitative PCR}

Total RNA from the liver and white muscle tissues ( $n 5$ per tissue) was extracted using an RNeasy Lipid Tissue Mini Kit (Qiagen) to ensure quality total RNA from lipid-dense tissues. Total RNA concentrations were quantified using spectrophotometry, and RNA purity was verified using the Nanodrop ND-1000 (Thermo Scientific). First-strand complementary DNA (cDNA) was synthesised using QuantiTect Reverse Transcription Kit (Qiagen). mRNA expression was quantified in duplicate using a Stratagene MX3000P real-time PCR machine (Stratagene) using Brilliant III Ultra-Fast SYBR green qPCR mix (Agilent Technologies). Each reaction contained $10 \mu \mathrm{L}$ SYBR mix, $1 \mu \mathrm{l}$ forward and reverse primers $(100 \mu \mathrm{M}), 0.375 \mu \mathrm{l}$ ROX reference dye (1:500 dilution), $6.7 \mu$ l RNase/DNase-free water, and $1 \mu \mathrm{l} 5 \times$ diluted cDNA template. Cycling conditions were: $3 \mathrm{~min}$ initial denaturation at $95^{\circ} \mathrm{C}$, forty cycles of $95^{\circ} \mathrm{C}$ for $20 \mathrm{~s}$, and $60^{\circ} \mathrm{C}$ for $20 \mathrm{~s}$. To account for differences in amplification efficiencies between different cDNA, standard curves were constructed for each target gene using serial dilutions of quantified liver and muscle cDNA. To account for the differences in cDNA production and loading differences, all samples were normalised to the expression level of the housekeeping gene 18S, which did not change over the experimental treatments. Transcript expression data were calculated using the $2^{\Delta \Delta-C_{\mathrm{t}}} \operatorname{method}^{(25)}$. Both RNase/DNasefree water and non-reverse transcribed RNA were assayed on each plate to ensure no contamination was present in the reagents or in the primers used. Primers were either designed using Primer 3 software ${ }^{(26)}$ or taken from previously validated primers sets ${ }^{(27)}$. Target genes of interest were: Adipo, AMPK $\alpha$ subunit 1 (AMPK $\alpha 1), C P T 1, F A S, G K, H K, P G C 1 \alpha$, $P P A R \alpha$ and SREBP1. Primers and accession numbers can be found in Table 2.

\section{Statistical analyses}

All data are presented as the mean with their standard errors. Statistical significance between all treatments was determined using a one-way ANOVA followed by a Tukey's post hoc test. Where appropriate, a Student's $t$ test was applied to determine significant differences within a carbohydrate load (i.e. $12 \%+v .12 \%-$ ). The level of significance for all tests was set at $P<0.05$, and all statistical analyses were performed on SigmaPlot 11.0 software (Systat Software, Inc.).

\section{Results \\ General parameters}

Although all fish had significant weight gains over the course of the 8 -week period, trout that were fed a $22 \%$ carbohydrate diet, independent of MR, increased their mean body weight by $87 \cdot 4$ and $81.4 \%(22 \%+$ and $22 \%$ - , respectively) compared to the approximately $40 \%$ increase seen in fish fed a diet composed of $12 \%$ carbohydrate (Table 3 ). As an estimate of fish metabolic rate, whole-tank oxygen consumption was assessed $6 \mathrm{~h}$ post-feeding; whole-tank $\mathrm{MO}_{2}$ increased by 1.6-fold in the $22 \%$ group, and value significantly different from any of the other treatments (Table 3). Hepatosomatic index, used as a measure of total hepatic energy storage, significantly increased

Table 2. Forward $(F)$ and reverse $(R)$ primers used for quantitative $P C R$, including amplicon length

\begin{tabular}{|c|c|c|c|c|}
\hline Gene & Description & Primer & Length & Genbank accession no. \\
\hline Adipo & Adiponectin & $\begin{array}{l}\text { F: CGC CCT GTT GTA TCA TTC CT } \\
\text { R: TTC CGC TCA CGT CAT CAT AG }\end{array}$ & 125 & AB604654 \\
\hline$A M P k \alpha 1$ & AMP-activated protein kinase $\alpha$ subunit 1 & $\begin{array}{l}\text { F: ATC TTC TTC ACG CCC CAG TA } \\
\text { R: GGG AGC TCA TCT TTG AAC CA }\end{array}$ & 131 & HQ40367 \\
\hline CPT1 & Carnitine palmitoyl transferase 1 & $\begin{array}{l}\text { F: GCA CTG CAA AGG AGA CAT CA } \\
\text { R: GCT ATC ACC TTG GCA ACC AT }\end{array}$ & 117 & AF327058 \\
\hline$F_{A S}^{(26)}$ & Fatty acid synthase & $\begin{array}{l}\text { F: GAG ACC TAG TGG AGG CTG TC } \\
\text { R: TCT TGT TGA TGG TGA GCT GT }\end{array}$ & 59 & \\
\hline GK & Glucokinase & $\begin{array}{l}\text { F: CAG GAG GCC AGT GTC AAA AT } \\
\text { R: CAA CCT TCA CCA ACA TCA CA }\end{array}$ & 124 & NM01124249 \\
\hline$H K$ & Hexokinase & $\begin{array}{l}\text { F: TCA TCG TCA AGG AGG TAT GC } \\
\text { R: AGC CCT CTG TTC TCA CGA AT }\end{array}$ & 103 & AY864082 \\
\hline$P G C 1 \alpha$ & PPAR $\gamma$ coactivator $1 \alpha$ & $\begin{array}{l}\text { F: TCC TCT ATC GCC TCC AAG AA } \\
\text { R: GAT CCC TTG TGG TCA TTT GA }\end{array}$ & 125 & FJ710611 \\
\hline$P P A R \alpha$ & $\operatorname{PPAR} \alpha$ & $\begin{array}{l}\text { F: TCA TCA CCA GGG AGT TCC TC } \\
\text { R: TCA CTG TCA TCC AGC TCC AG }\end{array}$ & 109 & HM536190 \\
\hline$S R E B P 1^{(26)}$ & Sterol-regulatory element binding protein 1 & $\begin{array}{l}\text { F: GAC AAG GTG GTC CAG TTG CT } \\
\text { R: CAC ACG TTA GTC CGC ATC AC }\end{array}$ & 60 & \\
\hline $18 s$ & 18s ribosomal RNA & $\begin{array}{l}\text { F: ATG GCC GTT CTT AGT TGG TG } \\
\text { R: CTC AAT CTC GTG TGG CTG AA }\end{array}$ & 146 & FJ710873 \\
\hline
\end{tabular}


Table 3. Effects of varying carbohydrate load and methionine restriction in Oncorhynchus mykiss on weight (g); whole-tank metabolic rate $\left(\mathrm{MO}_{2} ; \mathrm{mg} \mathrm{O}_{2} / \mathrm{kg}\right.$ fish per h); hepato-somatic index (HSI); haematocrit (HCT); plasma TAG and cholesterol (mmol/l); tissue TAG, cholesterol, phospholipids, and total lipids (mg/g tissue); adenylate energy charge (AEC)

(Mean values with their standard errors and percentages)

\begin{tabular}{|c|c|c|c|c|c|c|c|c|}
\hline & \multicolumn{2}{|c|}{$12 \%+$} & \multicolumn{2}{|c|}{$12 \%-$} & \multicolumn{2}{|c|}{$22 \%+$} & \multicolumn{2}{|c|}{$22 \%-$} \\
\hline & Mean & SEM & Mean & SEM & Mean & SEM & Mean & SEM \\
\hline \multicolumn{9}{|l|}{ Weight } \\
\hline Initial & $82 \cdot 3$ & 4.0 & 73.6 & $6 \cdot 0$ & $72 \cdot 3$ & $5 \cdot 3$ & 68.0 & $4 \cdot 1$ \\
\hline Final & $121 \cdot 0$ & $14 \cdot 1$ & 104.4 & $14 \cdot 0$ & $135 \cdot 6$ & 14.4 & $123 \cdot 3$ & $17 \cdot 7$ \\
\hline Increase (\%) & 46.9 & & 41.8 & & 87.4 & & 81.4 & \\
\hline Tank $\mathrm{MO}_{2}$ & $221 \cdot 8^{\mathrm{a}}$ & $13 \cdot 1$ & $214 \cdot 5^{\mathrm{a}}$ & $16 \cdot 8$ & $270 \cdot 3^{\mathrm{a}}$ & 14.0 & $355 \cdot 9^{b}$ & $26 \cdot 1$ \\
\hline HIS & $1 \cdot 18^{\mathrm{a}}$ & 0.07 & $1 \cdot 70^{\mathrm{b}}$ & 0.06 & $1 \cdot 35^{\mathrm{a}, \mathrm{b}}$ & 0.11 & $2 \cdot 38^{\mathrm{C}}$ & 0.23 \\
\hline HCT & $47 \cdot 3^{\mathrm{a}}$ & 2.4 & $38 \cdot 1^{\mathrm{b}}$ & 2.5 & $44 \cdot 0^{\mathrm{a}, \mathrm{b}}$ & 1.5 & $37.0^{\mathrm{b}}$ & $2 \cdot 0$ \\
\hline Plasma TAG & 0.58 & $0 \cdot 10$ & 0.48 & 0.04 & 0.61 & 0.14 & 0.61 & 0.16 \\
\hline \multirow{2}{*}{\multicolumn{9}{|c|}{ Liver tissue }} \\
\hline & & & & & & & & \\
\hline TAG & $24 \cdot 0^{a}$ & 2.9 & $12 \cdot 6^{\mathrm{b}}$ & 3.4 & $24 \cdot 7^{\mathrm{a}}$ & $3 \cdot 3$ & $28 \cdot 6^{a}$ & $6 \cdot 8$ \\
\hline Cholesterol & $17 \cdot 1^{\mathrm{a}}$ & 0.8 & $23 \cdot 7^{b}$ & 0.6 & $17 \cdot 1^{a}$ & 0.7 & $11 \cdot 2^{\mathrm{c}}$ & 1.1 \\
\hline Phospholipids & $96 \cdot 3^{a}$ & $5 \cdot 8$ & $78 \cdot 6^{\mathrm{b}}$ & 3.9 & $86 \cdot 4^{\mathrm{c}}$ & $5 \cdot 1$ & $63 \cdot 1^{d}$ & $5 \cdot 3$ \\
\hline Total lipids & $232 \cdot 2^{\mathrm{a}}$ & $14 \cdot 4$ & $166 \cdot 6^{\mathrm{b}}$ & 21.6 & $240 \cdot 6^{a}$ & 8.6 & $171 \cdot 6^{\mathrm{b}}$ & 18.9 \\
\hline AEC & 0.879 & 0.027 & 0.890 & 0.021 & 0.939 & 0.007 & $0.881^{*}$ & 0.022 \\
\hline \multicolumn{9}{|l|}{ Muscle tissue } \\
\hline TAG & $24.9^{a}$ & 3.8 & $38.1^{\mathrm{b}}$ & 5.9 & $58 \cdot 7^{c}$ & 4.8 & $36 \cdot 9^{b}$ & $2 \cdot 2$ \\
\hline Cholesterol & $3 \cdot 8^{a}$ & 0.2 & $4 \cdot 3^{\mathrm{b}}$ & 0.1 & $4 \cdot 6^{\mathrm{c}}$ & 0.3 & $3 \cdot 7^{\mathrm{a}}$ & 0.2 \\
\hline Phospholipids & $40 \cdot 8^{\mathrm{a}}$ & 1.7 & $36 \cdot 3^{\mathrm{b}}$ & 3.9 & $47.9^{c}$ & 2.4 & $42 \cdot 6^{\mathrm{a}}$ & 3.3 \\
\hline Total lipids & $110 \cdot 5^{a}$ & $15 \cdot 3$ & $110 \cdot 3^{a}$ & $23 \cdot 3$ & $157 \cdot 4^{\mathrm{b}}$ & 13.9 & $127 \cdot 9^{a}$ & 9.5 \\
\hline AEC & $0.853^{a}$ & 0.018 & $0.768^{\mathrm{b} *}$ & 0.018 & $0.802^{\mathrm{a}, \mathrm{b}}$ & 0.022 & $0.749^{b *}$ & 0.011 \\
\hline
\end{tabular}

in both the $12 \%$ - and $22 \%$ - groups, an increase significantly correlated with liver tissue glycogen (see Fig. 1(C); linear regression, $R^{2} 0.548, P<0.001$ ). Haematocrit generally decreased with MR, although this was significantly different only in the $12 \%+$ group (Table 3 ). No significant changes occurred in plasma TAG levels, although a significant $1 \cdot 7$-fold decrease in circulating cholesterol levels in the $12 \%$ - treatment compared to the $12 \%+$ group occurred. Similar trends in cholesterol content between the $22 \%-$ and $22 \%+$ fish were observed, although neither treatments were different from their respective controls (Table 3 ).

\section{Lipids and adenylates}

Fish fed MR diets at both carbohydrate levels significantly decreased total lipid content in the liver, attributed to the significantly decreased levels of cholesterol and phospholipid in the $22 \%$ group, and decreased TAG in both MR treatments (Table 3). Despite a shift in fuel supply in the liver, the AEC remained unchanged across treatments. In muscle tissue, there is little change in the total lipid content, except for a significant increase in the $22 \%+$ group. However, there were significant changes associated with TAG, cholesterol and phospholipids in the treatment groups. At 12\% carbohydrate, MR significantly increased TAG and cholesterol levels, and decreased phospholipids (Table 3), while at $22 \%$ carbohydrate all three parameters increased, which probably contributed to the total lipid increase. In contrast, the $22 \%-$ group demonstrated no differences in total lipids, cholesterol or phospholipids when compared to the control group $(12 \%-)$, even though TAG increased significantly. Thus, MR apparently contributed towards the reduction in total lipids when compared to the $22 \%+$ group (Table 3 ). Muscle adenylates were affected substantially by both dietary carbohydrate and MR, unlike in the liver tissue. AEC was significantly different in both MR groups.

\section{Transcript expression}

Expressed as a ratio of the $12 \%+$ treatment (control) group, variable expressional patterns of transcripts across treatments and between tissues persisted. Although there was no change in transcript expression of Adipo in the liver, the normalised expression level (not expressed as a ratio of the control group), was 3-1-times lower in the liver than transcript levels found in the muscle $(12 \%+$ group comparison), suggesting that the primary site of expression of Adipo is muscle tissue as previously proposed for rainbow trout ${ }^{(28)}$. Expression of Adipo transcripts in the muscle decreased by $2-3$-fold with MR, but increased 2 -fold in the $22 \%+$ group (Table 4). AMPK $\alpha 1$ expression increased 2 -fold in the liver of the $22 \%$ - group, whereas transcripts increased by $2 \cdot 1$-fold in the muscle in the $12 \%$ - diet, with non-significant changes noted in both $22 \%$ carbohydrate diets. There was a 3 -fold increase in CPT1 transcript levels in the livers of $22 \%$ - fish, and white muscle CPT1 levels were approximately 3- to 5-fold higher with MR when compared to their respective carbohydrate load (Table 4). MR decreased FAS transcript level in 

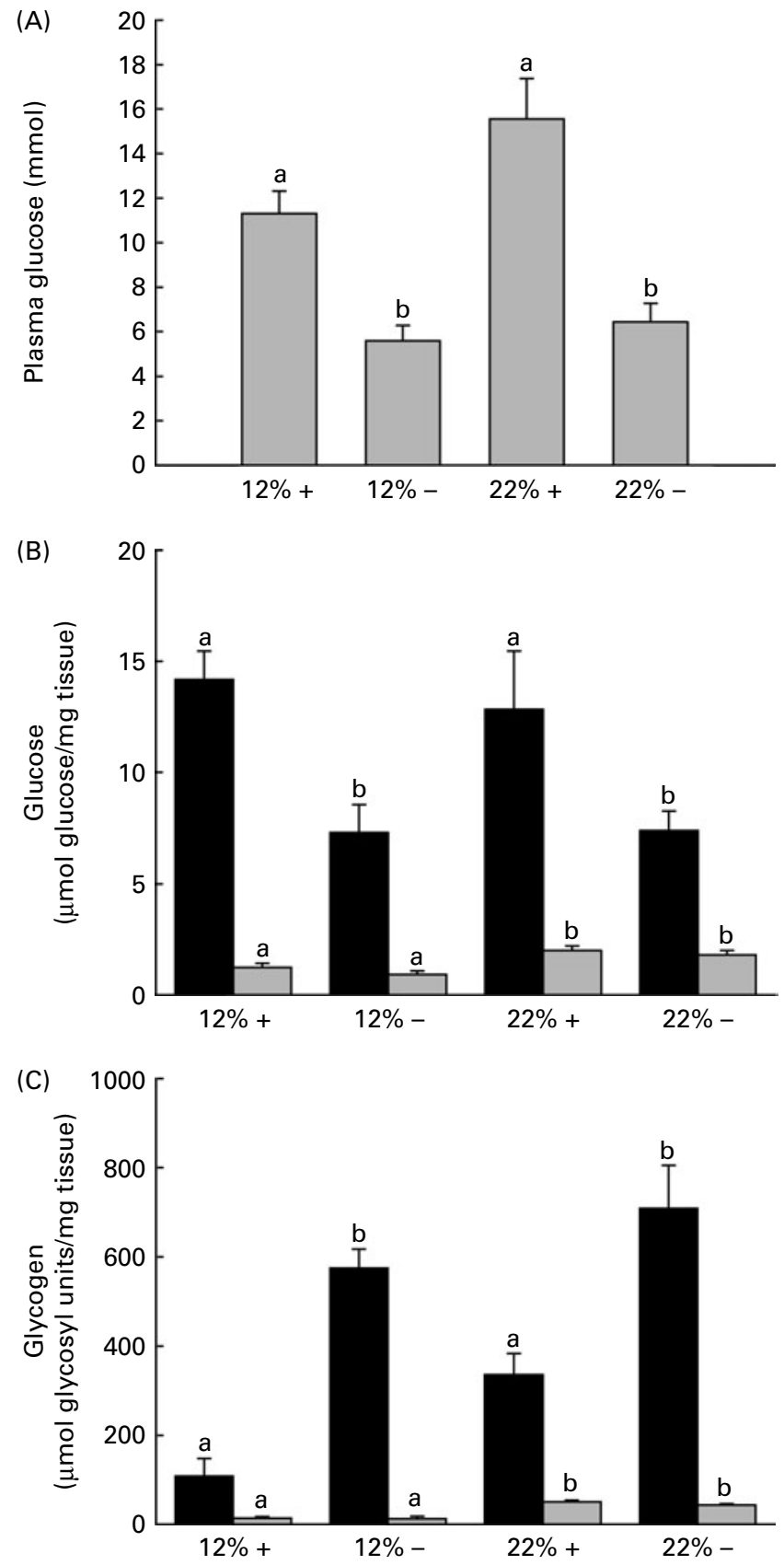

Fig. 1. Effects of dietary manipulation of carbohydrate load and methionine restriction on (A) plasma glucose ( $\mathrm{mmol} / \mathrm{l})$ and liver $(\boldsymbol{\square})$ and muscle $(\square)$ tissue (B) glucose ( $\mu \mathrm{mol}$ glucose/mg tissue) and (C) glycogen ( $\mu \mathrm{mol}$ glycosyl units/mg tissue) levels $6 \mathrm{~h}$ post-feeding in Oncorhynchus mykiss. ${ }^{\mathrm{a}, \mathrm{b}}$ Mean values for a tissue (liver or muscle) with unlike letters were significantly different $(P<0.05$; one-way ANOVA and Tukey's post hoc test). $12 \%+, 12 \%$ Carbohydrate load with $1.5 \%$ methionine content; $12 \%-, 12 \%$ carbohydrate load with $0 \%$ methionine; $22 \%+, 22 \%$ carbohydrate load with $1.5 \%$ methionine content; $22 \%$ - , $22 \%$ carbohydrate load with $0 \%$ methionine.

the liver independent of carbohydrate load, while the expression did not change in the muscle. GK in the liver was significantly repressed in the trout fed MR diets, and HK in the muscle was attenuated only with MR in the $22 \%$ carbohydrate treatment group. The $22 \%$ carbohydrate diet increased PGC1 $\alpha$ transcript levels, although MR attenuated this response. Likewise, MR decreased PGC1 $\alpha$ transcript levels in the
$12 \%$ - treatment when compared to the $12 \%+$ group. MR imposed a significant depression on PPAR $\alpha$ transcript levels in the liver independent of carbohydrate load. SREBP1 transcript levels varied, with MR decreasing expression levels when compared to their respective carbohydrate control. Likewise, the muscle displayed decreased transcription levels of SREBP1 with MR, and nearly a 2 -fold significant increase in transcript content in the $22 \%+$ group.

\section{Glucose and glycogen levels}

One dramatic response to MR is the reduction in circulating plasma glucose $6 \mathrm{~h}$ post-feeding in a normally glucose-intolerant species (Fig. 1(A)). It should be noted that when compared alone, there is a significant difference ( $t$ test, $P=0.029)$ between the $12 \%+$ and $22 \%+$ groups (Fig. 1(A)). Consistent with this reduced plasma glucose content is a $50 \%$ reduction in liver glucose independent of carbohydrate level and a 6-8-fold increase in glycogen content depending on the carbohydrate level fed to the trout (Fig. 1(B) and (C)). The response in the muscle was not as dramatic although here the level of carbohydrate fed dictated the observed increase in glucose and glycogen content; there were no MR-dependent effects.

\section{Enzymatic activity}

GK and HK activity was assessed in the liver and white muscle, respectively. MR appears to down-regulate GK activity in the liver, with a significant effect in the $22 \%$ carbohydrate group (Fig. 2). Likewise, there is a depression in HK activity in the $22 \%$ carbohydrate group with MR, and there were no significant changes in either tissue associated with a $12 \%$ carbohydrate load.

\section{Total DNA methylation}

Diet is reported to significantly affect the extent of total DNA methylation. Thus the percentage of $5-\mathrm{mC}$ was determined in both the liver and muscle tissues. Dietary carbohydrate content rather than Met content plays a more significant role in defining the overall methylation status of DNA, as the percentage $5-\mathrm{mC}$ present in both $22 \%+$ and $22 \%$ - groups significantly decreased in both the liver and muscle (Fig. 3). However, at nominal levels of carbohydrates (12\%), there is a general decrease associated with MR, which may indicate that Met may have some role in dictating total methylation.

\section{Discussion}

The aim of the present study was to expand our knowledge of carbohydrate handling in a carnivorous fish species, the rainbow trout, and to assess the phenotypic effects of Metdeficient (MR) diets primarily on glucose metabolism. The results demonstrated that rainbow trout fed an isoenergetic/ isonitrogenous diet, but containing $22 \%$ rather than $12 \%$ digestible carbohydrate, nearly doubled their weight gain over an 8-week feeding regimen. Importantly, this weight gain occurred even though levels of fish oil in the $22 \%$ diets 
Table 4. Effects of varying carbohydrate load and methionine restriction in Oncorhynchus mykiss on the transcript expression in the liver and muscle tissue of adiponectin (Adipo); AMP-activated protein kinase $\alpha$ subunit 1 (AMPK $\alpha 1$ ); carnitine palmitoyl transferase 1 (CPT1), fatty acid synthase (FAS); glucokinase (GK; liver only); hexokinase (HK; muscle only); PPAR y coactivator $1 \alpha(P G C 1 \alpha)$; PPAR ; sterolregulatory element binding protein $1(S R E B P 1)^{\star}$

(Mean values with their standard errors)

\begin{tabular}{|c|c|c|c|c|c|c|c|c|}
\hline \multirow[b]{2}{*}{ Gene } & \multicolumn{2}{|c|}{$12 \%+$} & \multicolumn{2}{|c|}{$12 \%-$} & \multicolumn{2}{|c|}{$22 \%+$} & \multicolumn{2}{|c|}{$22 \%-$} \\
\hline & Mean & SEM & Mean & SEM & Mean & SEM & Mean & SEM \\
\hline \multicolumn{9}{|l|}{ Liver tissue } \\
\hline Adipo & 1.00 & 0.27 & 0.50 & 0.21 & 0.31 & 0.16 & 0.57 & 0.12 \\
\hline$A M P K \alpha 1$ & $1.00^{\mathrm{a}}$ & 0.05 & $0.76^{\mathrm{a}}$ & 0.15 & $1.05^{\mathrm{a}}$ & 0.17 & $2.03^{b} t$ & 0.31 \\
\hline CPT1 & $1.00^{\mathrm{a}}$ & 0.14 & $1.47^{\mathrm{a}, \mathrm{b}}$ & 0.34 & $1 \cdot 10^{\mathrm{a}}$ & 0.47 & $3 \cdot 11^{b}+$ & 0.61 \\
\hline FAS & $1.00^{\mathrm{a}}$ & $0 \cdot 16$ & $0.29^{\mathrm{b}} t$ & 0.10 & $1 \cdot 31^{a}$ & 0.24 & $0.08^{\mathrm{b}} \dagger$ & 0.03 \\
\hline$G K$ & $1 \cdot 00^{\mathrm{a}, \mathrm{c}}$ & 0.29 & $0 \cdot 13^{b} t$ & 0.05 & $1.50^{\mathrm{a}}$ & 0.21 & $0.48^{\mathrm{b}, \mathrm{c}} \dagger$ & 0.13 \\
\hline$P G C 1 \alpha$ & $1.00^{\mathrm{a}}$ & 0.15 & $0.60^{a}+$ & 0.14 & $4 \cdot 44^{\mathrm{b}}$ & 0.72 & $2.02^{a}+$ & 0.31 \\
\hline$P P A R \alpha$ & $1.00^{\mathrm{a}}$ & 0.12 & $0.30^{b}+$ & 0.06 & $0.85^{\mathrm{a}}$ & 0.08 & $0.43^{b} \dagger$ & 0.07 \\
\hline SREBP1 & $1.00^{a, b}$ & $0 \cdot 16$ & $0.40^{a}+$ & 0.07 & $2 \cdot 30^{\mathrm{C}} \dagger$ & 0.31 & $1.55^{\mathrm{b}, \mathrm{c}}$ & 0.25 \\
\hline \multicolumn{9}{|l|}{ Muscle tissue } \\
\hline Adipo & $1.00^{\mathrm{a}}$ & 0.22 & $0.29^{b} \dagger$ & 0.05 & $2 \cdot 03^{c}$ & 0.42 & $0.48^{\mathrm{b}} \dagger$ & 0.07 \\
\hline AMPK $\alpha 1$ & $1.00^{\mathrm{a}}$ & 0.18 & $2 \cdot 10^{\mathrm{b} t}$ & 0.17 & $1.61^{a, b}$ & 0.13 & $1.86^{a, b}$ & 0.35 \\
\hline CPT1 & $1.00^{\mathrm{a}}$ & 0.25 & $3 \cdot 37^{a, b} \dagger$ & 0.79 & $0.95^{\mathrm{a}}$ & 0.23 & $5 \cdot 11^{b} \dagger$ & 1.32 \\
\hline FAS & 1.00 & 0.35 & 0.65 & $0 \cdot 17$ & $1 \cdot 17$ & 0.32 & 0.62 & 0.37 \\
\hline$H K$ & $1.00^{\mathrm{a}}$ & 0.27 & $1 \cdot 23^{a}$ & 0.14 & $2 \cdot 60^{\mathrm{b}}$ & 0.29 & $1 \cdot 31^{\mathrm{a}}+$ & 0.31 \\
\hline$P G C 1 \alpha$ & 1.00 & 0.19 & 0.86 & 0.12 & 1.51 & 0.21 & $0.77 \dagger$ & 0.14 \\
\hline$P P A R \alpha$ & 1.00 & 0.24 & 1.09 & 0.22 & 1.29 & 0.18 & 1.02 & 0.13 \\
\hline SREBP1 & $1 \cdot 00^{a, b}$ & 0.22 & $0.33^{\mathrm{a}} \dagger$ & 0.10 & $1.97^{b}$ & 0.48 & $0.26^{a} \dagger$ & 0.06 \\
\hline
\end{tabular}

$12 \%+, 12 \%$ Carbohydrate load with $1.5 \%$ methionine content; $12 \%-, 12 \%$ carbohydrate load with $0 \%$ methionine; $22 \%+, 22 \%$ carbohydrate load with $1.5 \%$ methionine content; $22 \%-, 22 \%$ carbohydrate load with $0 \%$ methionine.

a,b,c Mean values within a row with unlike superscript letters are significantly different (one-way ANOVA and Tukey's post hoc test; $P<0.05$ ).

*Transcript expression was normalised to $18 \mathrm{~S}$ ribosomal RNA and values are expressed as a ratio of the $12 \%+$ treatment group.

† Mean values are significantly different within a given carbohydrate load (i.e. $12 \%+v .12 \%-; t$ test, $P<0.05$ ).

were nearly $50 \%$ of those in the $12 \%$ diets. This weight gain was independent of Met, but the MR diet prevented the hyperglycaemia associated with glucose feeding irrespective of the carbohydrate load. In an effort to determine how glucose metabolism was altered with MR, phenotypic and transcriptional parameters related to carbohydrate and lipid metabolism were assessed in the muscle and liver tissues. Finally, since Met is a significant contributor to the total tissue methyl pool, total genomic DNA methylation was quantified, and results indicated that the higher carbohydrate content had a greater impact on decreasing DNA methylation than MR itself, indicating that diet has a significant role in the epigenetic regulation of gene transcription in the trout.

\section{Carbohydrate and lipid metabolism}

Glucose intolerance in carnivorous fish is well established ${ }^{(29,30)}$, and this is associated with carbohydrate-enriched meals increasing glycolytic capacity while failing to repress the gluconeogenic capacity of the liver ${ }^{(24,31-33)}$. Our studies with trout fed the $12 \%+$ and $22 \%+$ diets further support these findings, as the liver displayed significantly high glucose levels with reduced glycogen storage when compared to MR-fed trout (Fig. 1(B) and (C)). Likewise, there were increases in the glycolytic enzymes GK and $\mathrm{HK}$ in the liver and muscle associated with $22 \%+$ diet (Fig. 2). However, trout fed the MR diets reversed this trend, where there was a significant increase in liver glycogen stores and reduced glucose pools, with a significant repression in the glycolytic activity of liver GK and muscle HK, particularly in the $22 \%$ group. As there was a significant decrease in glycaemia, the hepatic glucose pool may have been stored as glycogen, although further evidence is required. This hypoglycaemicphenotype was also seen in rainbow trout fed metformin, an anti-diabetic drug prescribed in humans ${ }^{(26)}$. However, this phenotype is associated with an increased lipogenic capacity, with increased mRNA levels for glucose-6-phosphate dehydrogenase and FAS in trout fed metformin + high carbohydrate load. The authors hinted at the potential for glucose biotransformation into fatty acids, a process demonstrated to be inefficient in rainbow trout ${ }^{(34)}$; a further study by Polakof et al. ${ }^{(19)}$ did demonstrate excess carbohydrate storage as lipids. With significantly higher glycogen loads, biotransformation of glucose to fatty acids seems unlikely with MR. Also, contrary to the metformin studies, MR significantly reduced the total lipid pool in the liver, with reductions in phospholipids and TAG, although this effect was more pronounced in the $22 \%$ group (Table 3). This may represent an increase in liver fat oxidation, as there was a significant reduction in hepatic lipogenic transcripts and in particularly FAS (Table 4). Although Plaisance et $a l .{ }^{(9)}$ did not measure transcription responses to MR in human subjects, they reported increased fat oxidation and decreased hepatic lipid content associated with a 16-week MR diet in obese adults. Although our study took a cursory look at MR-associated lipid metabolism, further studies are warranted to examine significant changes in key lipogenic (FAS) and $\beta$-oxidation (CPT-1, 3-hydroxyacyl-CoA dehydrogenase) enzymes activities. 

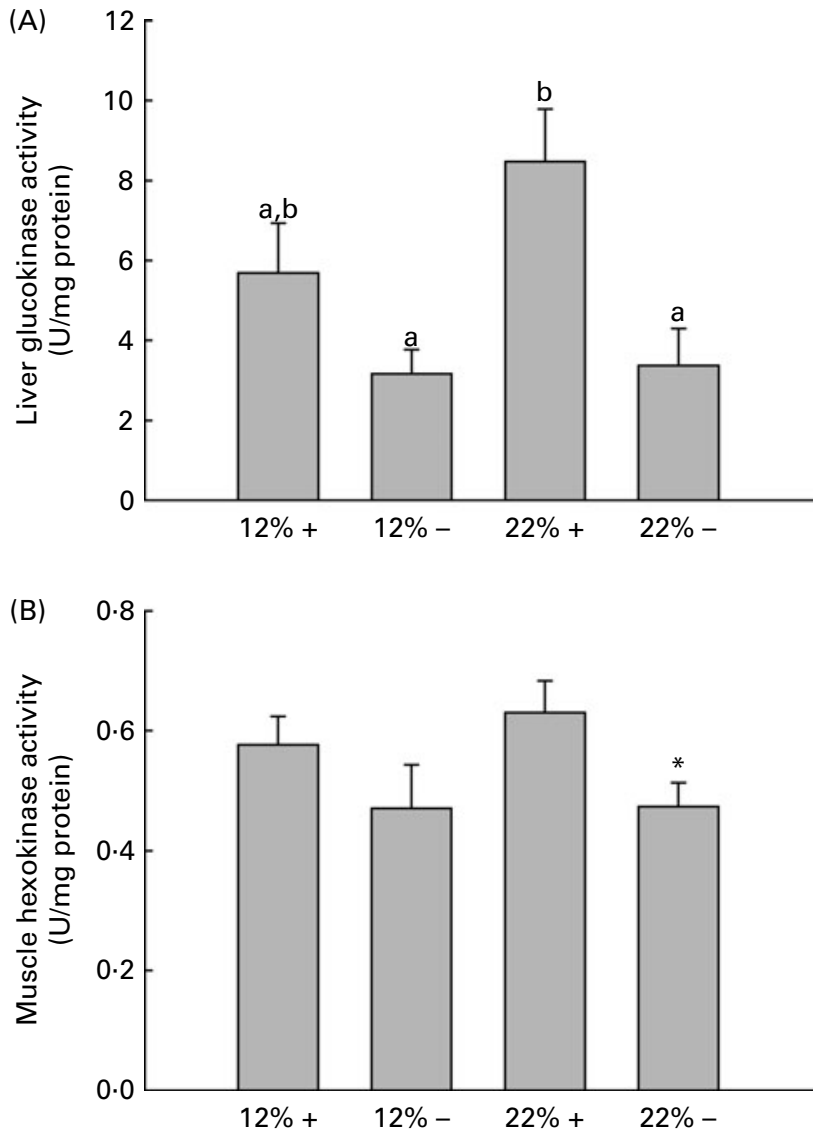

Fig. 2. Effects of dietary manipulation of carbohydrate load and methionine restriction on (A) liver glucokinase (GK) and (B) muscle HK activities measured as $\mathrm{U} / \mathrm{mg}$ protein. ${ }^{\mathrm{a}, \mathrm{b}}$ Mean values with unlike letters were significantly different $\left(P<0.05 ; t\right.$ test). ${ }^{*}$ Mean value was significantly different from that for the $22 \%+$ condition $(P<0.05 ; t$ test). $12 \%+, 12 \%$ Carbohydrate load with $1.5 \%$ methionine content; $12 \%-, 12 \%$ carbohydrate load with $0 \%$ methionine; $22 \%+, 22 \%$ carbohydrate load with $1.5 \%$ methionine content; $22 \%-, 22 \%$ carbohydrate load with $0 \%$ methionine.

A hepato-centric approach is often taken when examining carbohydrate metabolism in fish, but attention to other peripheral tissues including white muscle is warranted. Although rainbow trout, and other carnivorous species, are deemed 'glucose intolerant', the mechanisms are not entirely clear, although peripheral tissues are probably involved as extensive work has examined insulin release and the increase in insulin receptor activity in peripheral tissues after a carbohydraterich meal ${ }^{(19,35-38)}$. Conclusions of these studies suggest that muscle tissues readily respond to elevated plasma insulin induced by large carbohydrate loads to absorb circulating glucose, thereby enhancing the capacity of the animal to deal with a high glucose load. Here, although circulating insulin levels were not assessed, trout responded to a $22 \%$ carbohydrate load by increasing white muscle glucose and glycogen concentrations, irrespective of Met content (Fig. 1(B) and (C)). Likewise, there was a significant increase in total lipid content, although MR appears to have attenuated lipid accumulation in the muscle, specifically when comparing the $22 \%+$ and $22 \%$ - treatments. Similar results are reported in mammalian studies where non-obese rats fed an MR diet did not

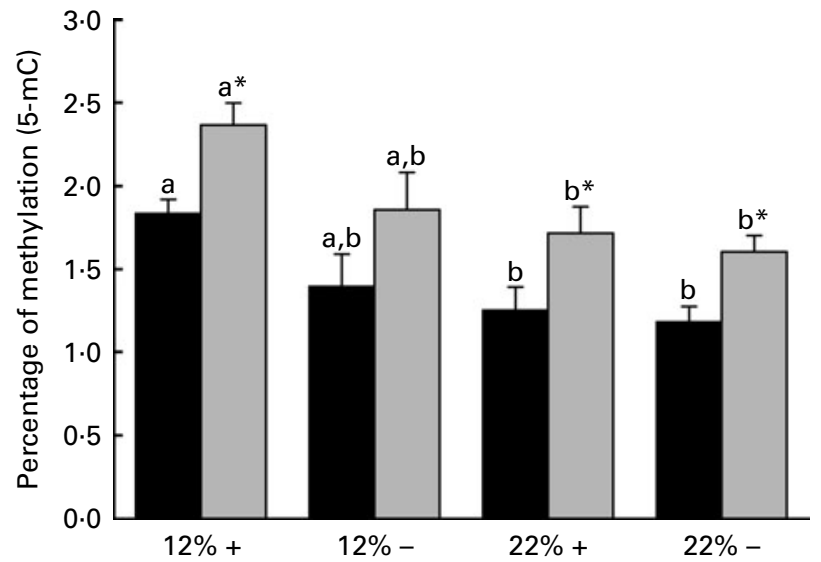

Fig. 3. Effects of dietary manipulation of carbohydrate load and methionine restriction on the percentage of methylation (5-methylcytosine; 5-mC) of genomic DNA in both liver ( $\boldsymbol{\square}$ ) and muscle $(\square)$ tissues harvested from Oncorhynchus mykiss $6 \mathrm{~h}$ post feeding. ${ }^{\mathrm{a}, \mathrm{b}}$ Mean values for a tissue (liver or muscle) with unlike letters were significantly different $(P<0.05$; one-way ANOVA and Tukey's post hoc test). ${ }^{*}$ Mean value was significantly different from that for liver $(P<0.05 ; t$ test $) .12 \%+, 12 \%$ Carbohydrate load with $1.5 \%$ methionine content; $12 \%-, 12 \%$ carbohydrate load with $0 \%$ methionine; $22 \%+, 22 \%$ carbohydrate load with $1.5 \%$ methionine content; $22 \%-, 22 \%$ carbohydrate load with $0 \%$ methionine.

accumulate fat over a 6-week feeding regimen, despite a paradoxical increase in food intake ${ }^{(20)}$. When obesity-prone rats were fed a similar MR diet, fat deposition was limited, and Hasek et al. ${ }^{(20)}$ suggested that increased energy expenditure was sufficient to compensate for the increased food intake and limit adiposity in both instances. The likely cause of this energy increase was deemed to be increased mitochondrial uncoupling, and a significant increase in uncoupling protein 1 was reported ${ }^{(20)}$. Trout fed a $22 \%$ diet displayed a $60 \%$ increase in tank-wise oxygen consumption, compared to the $12 \%+$ group, and a $30 \%$ increase over the $22 \%+$ group (Table 3 ). Probably, the increased oxygen consumption, which signified increased energy expenditure beyond a nominal increase related to postprandial digestion, may contribute to the reduction in lipid in the white muscle of MR trout. Further examination of energy expenditure in MR fish is needed, with specific examination of mitochondrial uncoupling and expression of uncoupling proteins.

\section{Transcript response}

Several transcripts responsible for energy homeostasis and lipid metabolism were estimated in the liver and muscle. The recently characterised adipokine in rainbow trout, Adipo ${ }^{(27)}$, is a hormone known to activate fatty acid oxidation, enhance glucose metabolism and regulate overall energy homeostasis in mammals ${ }^{(39-41)}$. Adipo in mammals is secreted from adipose tissue, but expression of Adipo transcripts was reported in the muscle and other tissues of rainbow trout but not adipose tissue $^{(27)}$. We find that absolute transcript levels were significantly higher in the white muscle compared to the liver in support of the report of Kondo et al. ${ }^{(28)}$. In the majority of mammalian studies, Adipo inversely correlates with percentage body fat, and elevated plasma Adipo stimulated glucose uptake 
and increased $\beta$-oxidation, effectively reducing metabolic syndromes such as type 2 diabetes ${ }^{(42,43)}$. In the $22 \%+$ treatment, there was a 2 -fold increase in Adipo expression in the muscle while the total lipid content increased, suggesting that the role of Adipo in lipid oxidation and glucose metabolism may differ in the fish species. Furthermore, MR appears to significantly reduce Adipo expression; further examination of Adipo transcript changes and its downstream effectors are required. However, the glycolytic transcripts, GK and HK, were significantly repressed, especially in hepatic tissues, and consistent with the enzymatic response of GK and HK in their respective tissues (Fig. 2).

Met reduction significantly reduced total liver lipid contents, which may indicate either a reduction in lipogenic capacity or an increase in fat oxidation, therefore reducing the overall hepatic lipid content. Hepatic mRNA transcripts for FAS, a regulator of fatty acid synthesis, and both hepatic and white muscle SREBP-1, a master regulator of cholesterol synthesis $^{(44)}$, were significantly reduced in fish fed MR diets. Likewise, there was a significant decrease in transcripts of PGC1 $\alpha$ and PPAR $\alpha$, both regulators of fat oxidation capacity ${ }^{(45,46)}$. Combined, these effects may suggest that MR diets result in reduced de novo synthesis of fatty acids and cholesterol, and additionally decreased $\beta$-oxidation, an indication that MR in trout may direct fuel usage away from fat oxidation towards carbohydrate usage, both factors that may help explain at least in part the observed reduction in lipid content of the liver. Moreover, CPT1, a key regulator of $\beta$-oxidation, was seen to increase in both the liver and muscle, especially with high carbohydrate loads, which suggests an increase in MR-associated fat oxidation. Although there is contradiction in the transcriptional response, caution is warranted in interpreting these data due to post-transcriptional modification and regulation. However, it is apparent that MR impacts the lipogenic and fat oxidation capacity in the liver and muscle of trout, and further in vitro validation of these mechanisms is currently being investigated.

Changes in fuel usage may impact energy availability. As a fuel source, fish utilise fats and proteins/amino acids more so than carbohydrates ${ }^{(47,48)}$. Although carbohydrate-enriched diets are shown to increase energy availability ${ }^{(26)}$, MR appears to decrease the available energy derived from carbohydrates. In the liver of $22 \%$ - treated trout, there is a significant decrease in the AEC compared to the $22 \%+$ group, which is indicative of a decrease in overall ATP content and increased ADP and AMP concentrations. Likewise, we see a significant decrease in the AEC in the white muscle of both MR groups. AMPK is a master regulator of cellular metabolism, and is activated when cellular concentrations of AMP increase ${ }^{(49)}$. The mRNA transcript for the catalytic subunit of AMPK, AMPK $\alpha 1$, was significantly up-regulated in both the liver and muscle tissues under these conditions (Table 4). Despite sufficient energy stores, in the form of carbohydrates in both the liver and muscle, there is a distinct decrease in available ATP, signified by the reduction in AEC and increased expression of AMPK $\alpha 1$. As demonstrated by Polakof et al. ${ }^{(19)}$, such changes could significantly affect lipogenic activities in trout. As noted previously, Hasek et al. ${ }^{(20)}$ demonstrated that
MR increased energy expenditure and mitochondrial uncoupling, which may contribute to the decrease in energy availability, although this warrants further investigation in trout.

\section{DNA methylation}

Diet is known to affect the epigenetic control of transcription, which in turn can dictate gene expression and physiological function $^{(50,51)}$. DNA methylation is key to the regulatory control of gene transcription, and evidence supports hyperand hypomethylated DNA-associated changes in gene expression ${ }^{(52,53)}$. The methyl pool necessary for DNA methylation is derived from $S$-adenosylmethionine, which is derived from Met adenylation ${ }^{(54)}$. One of our working hypotheses at the onset of this experiment was that if dietary Met was restricted, then a decrease in the degree of total DNA methylation, due to the lack of available methyl groups, would be observed. Interestingly, MR did not significantly affect total DNA methylation in either the liver or the white muscle of rainbow trout (Fig. 3). This suggests that MR may not limit the methyl pool available for DNA methylation, and may indicate other methyl sources or methylgenic pathways to compensate for the decrease in the methyl pool, such as betaine, choline and homocysteine re-methylation ${ }^{(55)}$. A more detailed examination of these pathways under the influence of MR is planned for future experiments. Although MR did not affect total DNA methylation as predicted, trout fed with the $22 \%$ carbohydrate diet had significantly reduced total DNA methylation in both the liver and muscle (Fig. 3). Diabetic rats have chronic alterations in methyl group metabolism with resulting genomic hypomethylation in hepatic tissues ${ }^{(56)}$. Although we abolished the primary 'glucose intolerant' phenotype with the reduction in postprandial plasma glucose in MR trout, fish fed carbohydrate-rich diets, irrespective of MR, still retained a glucose-intolerant phenotype with respect to DNA hypomethylation. A reduction in DNA methylation in trout fed the high-carbohydrate diet raises concerns related to gene expression, genomic stabilisation, and the possible development of secondary complications related to MR, such as cancer development ${ }^{(57-59)}$. Future efforts should be directed at understanding the methyl donor pathways and the effects of hypomethylation during MR in trout, which may provide greater insight into human-related metabolic syndromes.

\section{Conclusions}

Clearly, MR in rainbow trout elicits numerous phenotypic and transcriptional responses in the liver and white muscle tissue. Although we have not identified the direct pathways involved in the ability of MR to eliminate the glucose-intolerant phenotype in trout, it appears that the liver may play an essential role in the storage of excessive carbohydrates, which contributes to the abolishment of a hyperglycaemic phenotype after a carbohydrate-rich meal. However, peripheral tissues, such as white muscle, may be more important, as the mass of muscle tissue far exceeds that of the liver and probably provides a sink for the storage of excess carbohydrates in the 
form of lipids. Furthermore, there is a distinct possibility that MR-carbohydrate-enriched diets fed to fish initiate a switch in fuel usage, moving away from fat oxidation towards glucose metabolism, contrary to mammalian studies ${ }^{(20)}$. However, this switch related to MR appears to reduce the overall energy content available, particularly in the white muscle, suggesting uncoupled mitochondrial respiration. Finally, carbohydrate content does affect the overall hypomethylation status of genomic DNA in both liver and white muscle tissues. Further investigation into the enzymatic activity related to fat and glucose oxidation and examination of specific hypomethylated sites are required to understand the effects of MR in trout. Furthermore, trout fed MR diets provide useful systematic information for the better understanding of glucose-intolerant phenotypes and metabolic syndromes.

\section{Acknowledgements}

The authors wish to thank Bill Fletcher for his assistance in fish husbandry at the University of Ottawa. Thanks are also extended to Leslie Erdman for assistance in food preparation and feeding. P. M. C. designed and conducted the experiment and wrote the manuscript. T. W. M. provided experimental design and editorial input. The authors state that there is no conflict of interest associated with this paper. Funding was provided through a Natural Sciences and Engineering Council of Canada (NSERC) Discovery grant to T. W. M; P. M. C. is a recipient of an NSERC Postdoctoral Fellowship award.

\section{References}

1. Naylor RL, Goldburg RJ, Primavera JH, et al. (2000) Effect of aquaculture on world fish supplies. Nature 405, 1017-1024.

2. New MB \& Wijkstroem UN (2002) Use of Fishmeal and Fish Oil in Aquafeeds: Further Thoughts on the Fishmeal Trap. FAO Fisheries Circular no. 975. Rome: FAO.

3. Moon TW (2001) Glucose intolerance in teleost fish: fact or fiction? Comp Biochem Phys B 129, 243-249.

4. Hemre GI, Mommsen TP \& Krogdahl Å (2002) Carbohydrates in fish nutrition: effects on growth, glucose metabolism and hepatic enzymes. Aquac Nutr 8, 175-194.

5. Del sol Novoa M, Capilla E, Rojas P, et al. (2004) Glucagon and insulin response to dietary carbohydrate in rainbow trout (Oncorbynchus mykiss). Gen Comp Endocrinol 139, 48-54.

6. Sanz A, Caro P, Ayala V, et al. (2006) Methionine restriction decreases mitochondrial oxygen radical generation and leak as well as oxidative damage to mitochondrial DNA and proteins. FASEB J 20, 1064-1073.

7. Caro P, Gómez J, López-Torres M, et al. (2008) Forty percent and eighty percent methionine restriction decrease mitochondrial ROS generation and oxidative stress in rat liver. Biogerontology 9, 183-196.

8. Orentreich N, Matias JR, DeFelice A, et al. (1993) Low methionine ingestion by rats extends life span. J Nutr 123, 269-274.

9. Plaisance EP, Greenway FL, Boudreau A, et al. (2011) Dietary methionine restriction increases fat oxidation in obese adults with metabolic syndrome. J Clin Endocrinol Metab 96, E836-E840.

10. Shivapurkar N \& Poirier L (1983) Tissue levels of $S$-adenosylmethionine and $S$-adenosylhomocysteine in rats fed methyl- deficient, amino acid-defined diets for one to five weeks. Carcinogenesis 4, 1051-1057.

11. Pogribny IP, Ross SA, Wise C, et al. (2006) Irreversible global DNA hypomethylation as a key step in hepatocarcinogenesis induced by dietary methyl deficiency. Mutat Res 593, 80-87.

12. National Research Council (1993) Nutrient Requirement of Fish [Board of Agriculture and NRC, editors]. Washington, DC: National Academies Press.

13. Davies SJ \& Morris PC (1997) Influence of multiple amino acid supplementation on the performance of rainbow trout, Oncorbynchus mykiss (Walbaum), fed soya based diets. Aquacult Res 28, 65-74.

14. Cheng ZJ, Hardy RW \& Usry JL (2003) Effects of lysine supplementation in plant protein-based diets on the performance of rainbow trout (Oncorbynchus mykiss) and apparent digestibility coefficients of nutrients. Aquaculture 215, 255-265.

15. Gaylord TG \& Barrows FT (2009) Multiple amino acid supplementations to reduce dietary protein in plant-based rainbow trout, Oncorbynchus mykiss, feeds. Aquaculture 287, $180-184$

16. Espe M, Rathore R \& Du Z-Y (2010) Methionine limitation results in increased hepatic FAS activity, higher liver 18:1 to 18:0 fatty acid ratio and hepatic TAG accumulation in Atlantic salmon, Salmo salar. Amino Acids 39, 449-460.

17. Lansard M, Panserat S, Plagnes-Juan E, et al. (2010) Integration of insulin and amino acid signals that regulate hepatic metabolism-related gene expression in rainbow trout: role of TOR. Amino Acids 39, 801-810.

18. Lansard M, Panserat S, Plagnes-Juan E, et al. (2011) L-Leucine, L-methionine, and L-lysine are involved in the regulation of intermediary metabolism-related gene expression in rainbow trout hepatocytes. J Nutr 141, 75-80.

19. Polakof S, Médale F, Larroquet L, et al. (2011) Insulin stimulates lipogenesis and attenuates beta-oxidation in white adipose tissue of fed rainbow trout. Lipids 46, 189-199.

20. Hasek BE, Stewart LK, Henagan TM, et al. (2010) Dietary methionine restriction enhances metabolic flexibility and increases uncoupled respiration in both fed and fasted states. Am J Physiol Regul Integr Comp Physiol 299, R728-R739.

21. Panserat S, Skiba-Cassy S, Seiliez I, et al. (2009) Metformin improves postprandial glucose homeostasis in rainbow trout fed dietary carbohydrates: a link with the induction of hepatic lipogenic capacities? Am J Physiol Regul Integr Comp Physiol 297, R707-R715.

22. Hassid WZ \& Abraham S (1957) Chemical procedures for analysis of polysaccharides. In Methods Enzymology, pp. 34-37 [SP Colowick and NO Kaplan, editors]. New York, NY: Academic Press.

23. Bergmeyer HU (1983) Methods of Enzymatic Analysis New York, NY: Academic Press.

24. Panserat S, Medale F, Blin C, et al. (2000) Hepatic glucokinase is induced by dietary carbohydrates in rainbow trout, gilthead seabream, and common carp. Am J Physiol Regul Integr Comp Physiol 278, R1164-R1170.

25. Livak KJ \& Schmittgen TD (2001) Analysis of relative gene expression data using real-time quantitative PCR and the 2(-delta delta C(T)) method. Methods 25, 402-408.

26. Rozen S \& Skaletsky HJ (2000) Primer3 on the WwW for general users and for biologist programmers. In Bioinformatics Methods and Protocols: Methods in Molecular Biology, pp. 365-386 [S Krawetz and S Misener, editors]. New Jersey: Humana.

27. Skiba-Cassy S, Lansard M, Panserat S, et al. (2009) Rainbow trout genetically selected for greater muscle fat content display 
increased activation of liver TOR signaling and lipogenic gene expression. Am J Physiol Regul Integr Comp Physiol 297, R1421-R1429.

28. Kondo H, Suga R, Suda S, et al. (2011) EST analysis on adipose tissue of rainbow trout Oncorbynchus mykiss and tissue distribution of adiponectin. Gene $\mathbf{4 8 5}, 40-45$.

29. Furuichi M \& Yone Y (1982) Availability of carbohydrate in nutrition of carp and red sea bream. Bull Jpn Soc Sci Fish 48, 945-948.

30. Wilson RP \& Poe WE (1987) Apparent inability of channel catfish to utilize dietary mono- and disaccharides as energy sources. J Nutr 117, 280-285.

31. Panserat S, Medale F, Breque J, et al. (2000) Lack of significant long-term effect of dietary carbohydrates on hepatic glucose-6-phosphatase expression in rainbow trout (Oncorbynchus mykiss). J Nutr Biochem 11, 22-29.

32. Panserat S, Plagnes-Juan E, Breque J, et al. (2001) Hepatic phosphoenolpyruvate carboxykinase gene expression is not repressed by dietary carbohydrates in rainbow trout (Oncorbynchus mykiss). J Exp Biol 204, 359-365.

33. Panserat S, Plagnes-Juan E \& Kaushik S (2001) Nutritional regulation and tissue specificity of gene expression for proteins involved in hepatic glucose metabolism in rainbow trout (Oncorhynchus mykiss). J Exp Biol 204, 2351-2360.

34. Brauge C, Corraze G \& Médale F (1995) Effects of dietary levels of carbohydrate and lipid on glucose oxidation and lipogenesis from glucose in rainbow trout, Oncorbynchus mykiss, reared in freshwater or in seawater. Comp Biochem Phys $A$ 111, 117-124.

35. Gutierrez J, Asgard T, Fabbri E, et al. (1991) Insulin-receptor binding in skeletal muscle of trout. Fish Physiol Biochem 9, 351-360.

36. Párrizas M, Planas J, Plisetskaya EM, et al. (1994) Insulin binding and receptor tyrosine kinase activity in skeletal muscle of carnivorous and omnivorous fish. Am J Physiol Regul Integr Comp Physiol 266, R1944-R1950.

37. Bouraoui L, Capilla E, Gutierrez J, et al. (2010) Insulin and insulin-like growth factor I signaling pathways in rainbow trout (Oncorbynchus mykiss) during adipogenesis and their implication in glucose uptake. Am J Physiol Regul Integr Comp Physiol 299, R33-R41.

38. Polakof S, Skiba-Cassy S, Choubert G, et al. (2010) Insulininduced hypoglycaemia is coordinately regulated by liver and muscle during acute and chronic insulin stimulation in rainbow trout (Oncorbynchus mykiss). J Exp Biol 213 , $1443-1452$.

39. Fantuzzi G (2005) Adipose tissue, adipokines, and inflammation. J Allergy Clin Immunol 115, 911-919.

40. Guerre-Millo M (2008) Adiponectin: an update. Diabetes Metab 34, 12-18.

41. Savino F, Petrucci E \& Nanni GE (2008) Adiponectin: an intriguing hormone for paediatricians. Acta Paediatr 97, $701-705$.

42. Ukkola O \& Santaniemi M (2002) Adiponectin: a link between excess adiposity and associated comorbidities? J Mol Med 80, 696-702.
43. Nedvidkova J, Smitka K, Kopsky V, et al. (2005) Adiponectin, an adipocyte-derived protein. Physiol Res 54, 133-134.

44. Brown MS \& Goldstein JL (1997) The SREBP pathway: regulation of cholesterol metabolism by proteolysis of a membrane-bound transcription factor. Cell 89, 331-340.

45. Puigserver P \& Spiegelman BM (2003) Peroxisome proliferator-activated receptor-gamma coactivator 1 alpha (PGC-1 alpha): transcriptional coactivator and metabolic regulator. Endocr Rev 24, 78-90.

46. Kersten S, Seydoux J, Peters JM, et al. (1999) Peroxisome proliferator-activated receptor alpha mediates the adaptive response to fasting. J Clin Invest 103, 1489-1498.

47. Murai T, Yagisawa I, Akiyama T, et al. (1980) Protein, fat and carbohydrate sources of practical diet for fingerling chum salmon, Oncorbynchus keta. Bull Natl Res Inst Aquacult 1, 79-86.

48. Hilton JW \& Atkinson JI (1982) Response of rainbow trout (Salmo gairdneri) to increased levels of available carbohydrate in practical trout diets. Br J Nutr 47, 597-607.

49. Hardie DG (2007) AMP-activated/SNF1 protein kinases: conserved guardians of cellular energy. Nat Rev Mol Cell Biol 8, $774-785$.

50. Sandovici I, Smith NH, Ozanne SE, et al. (2008) Dynamic epigenome: the impact of the environment on epigenetic regulation of gene expression and developmental programming. In Epigenetics, pp. 343-370 [J Tost, editor]. Norfolk: Caister Academic.

51. Sandovici I, Smith NH, Nitert MD, et al. (2011) Maternal diet and aging alter the epigenetic control of a promoterenhancer interaction at the Hnf4a gene in rat pancreatic islets. Proc Natl Acad Sci US A 108, 5449-5454.

52. Holliday R \& Pugh JE (1975) DNA modification mechanisms and gene activity during development. Science 187, $226-232$.

53. Jenuwein $\mathrm{T}$ (2006) The epigenetic magic of histone lysine methylation. FEBS J 273, 3121-3135.

54. Mudd SH \& Poole JR (1975) Labile methyl balances for normal humans on various dietary regimens. Metabolism 24, 721-735.

55. Stead LM, Brosnan JT, Brosnan ME, et al. (2006) Is it time to reevaluate methyl balance in humans? Am J Clin Nutr $\mathbf{8 3}$, $5-10$.

56. Williams KT, Garrow TA \& Schalinske KL (2008) Type I diabetes leads to tissue-specific DNA hypomethylation in male rats. J Nutr 138, 2064-2069.

57. Coughlin SS, Calle EE, Teras LR, et al. (2004) Diabetes mellitus as a predictor of cancer mortality in a large cohort of US adults. Am J Epidemiol 159, 1160-1167.

58. Hassan MM, Hwang LY, Hatten CJ, et al. (2002) Risk factors for hepatocellular carcinoma: synergism of alcohol with viral hepatitis and diabetes mellitus. Hepatology 36, 1206-1213.

59. Rousseau MC, Parent ME, Pollak MN, et al. (2006) Diabetes mellitus and cancer risk in a population-based case-control study among men from Montreal, Canada. Int J Cancer 118, 2105-2109. 